Дитяча стоматологія

удК 616.31-083-053.71

DOI 10.11603/2311-9624.2019.3.10574

(С). П. Ярова, К. В. Новікова, Ю. Ю. Яров

Донецький національний медичний університет, м. Лиман

katyanovik93@gmail.com

\title{
Стан гігієни ротової порожнини та структура пародонтологічної патології у підлітків 15-16 років
}

\section{ІНФОРМАЦІЯ}

Надійшла до редакції/Received: 02.09.2019 p.

Ключові слова: діти; епідеміологія стоматологічних захворювань; гінгівіт; гігієна ротової порожнини.
Вступ. За даними провідних вітчизняних та іноземних науковців, стан гігієни ротової порожнини безпосередньо впливає на наявність запалення ясен, його поширеність, ступінь розвитку та визначає вид гінгівіту [1, 5-9].

Втрата значної частини зубів у молодому віці, наявність вогнищ хронічної інфекції, порушення основних функцій жувальномовного апарату, зниження якості життя хворих - далеко не повний перелік наслідків захворювань пародонта, які дозволяють розглядати дану патологію не тільки як серйозну медичну, а й важливу соціальну проблему $[6,7]$.
Незважаючи на те, що в даний час накопичені численні дані, що стосуються питань діагностики, профілактики та лікування захворювань пародонта, багато ключових аспектів виникнення пародонтиту та хронічного катарального гінгівіту залишаються недостатньо вивченими. Зокрема актуальними необхідно вважати дослідження, присвячені вивченню факторів, що сприяють розвитку запальних захворювань тканин пародонта. Провідним етіологічним чинником розвитку гінгівіту та парадонтиту є гігієна порожнини рота [5-7].

Метою дослідження було вивчити стан гігієни ротової порожнини та структури паро- 
донтологічної патології у підлітків віком 1516 років м. Краматорськ.

Матеріали і методи. Для реалізації мети дослідження було проаналізовано пародонтологічний статус 210 підлітків м. Краматорськ, які звернулися за консультативною пародон- тологічною допомогою на кафедру стоматології № 2 Донецького національного медичного університету з 2018 до 2019 рр., та визначено особливості гігієнічного догляду як фактора ризику формування та прогресування захворювань тканин пародонта (табл. 1).

таблиия 1. Поділ обстежених підлітків за статтю

\begin{tabular}{|c|c|c|c|c|c|c|}
\hline Стать & \multicolumn{2}{|c|}{ Хлопці } & \multicolumn{2}{c|}{ Дівчата } & \multicolumn{2}{c|}{ Усього } \\
\hline Вік (роки) & абс. & $\%$ & абс. & $\%$ & абс. & 100 \\
\hline $15-16$ & 112 & 53,3 & 98 & 46,7 & 210 & 10 \\
\hline
\end{tabular}

Обстеження дітей проводили за загальноприйнятою в стоматології методикою, яка включала збір скарг, анамнез життя і захворювання, зовнішній огляд дитини й огляд ротової порожнини, визначали індекси GreenVermillion і поширеність гінгівіту - за індексом PMA [4]. Інтенсивність запалення визначали за критеріями проби Шиллера-Писарєва [4].

Матеріали клінічного дослідження були піддані варіаційно-статистичній обробці відповідно до мети роботи. Обробку результатів дослідження проводили з використанням загальноприйнятих методів математичної статистики та лецінзійного пакета Statistica 8.0.

Результати досліджень та їх обговорення. Основною причиною для звернення за стома- тологічною допомогою більшість пацієнтів називали наявність кровоточивості ясен під час чищення зубів, ïi болючість, рихомість. Деякі самостійно відзначали гіперемію, набряк слизової і неприємний запах. Також фігурували такі скарги, як розростання ясен або рецесії ясен.

Встановлено, що середнє значення індексу PMA у підлітків відповідало середньо-тяжкому та тяжкому ступеням гінгівіту, тобто індекс РМА становив $(49,7 \pm 5,21) \%$, зокрема у хлопців - $(54,3 \pm 5,39) \%$, а у дівчат - $(45,0 \pm 3,20) \%$ (табл. 2$)$.

Дані, представлені в таблиці 3, свідчать про перевагу позитивної та слабопозитивної проби Шилера-Писарєва відповідно 40,6 та 40,5 \% від кількості усіх обстежених; негативною проба була у 18,7 \%.

таблищя 2. Папілярно-маргінально-альвеолярний індекс у підлітків 15-16 років (\%)

\begin{tabular}{|c|c|c|c|}
\hline Вік (роки) & $\begin{array}{c}\text { Хлопці } \\
(\mathrm{n}=112) \%\end{array}$ & $\begin{array}{c}\text { Дівчата } \\
(\mathrm{n}=98) \%\end{array}$ & $\begin{array}{c}\text { Середні значення } \\
(\mathrm{n}=210) \%\end{array}$ \\
\hline $15-16$ & $54,3 \pm 5,39$ & $45,0 \pm 3,20$ & $49,7 \pm 5,21$ \\
\hline
\end{tabular}

таблиця 3. Проба Шиллера-Писарєва у підлітків 15-16 років

\begin{tabular}{|l|c|c|c|c|c|c|}
\hline \multirow{2}{*}{ Проба } & \multicolumn{2}{|c|}{$\begin{array}{c}\text { Хлопці } \\
(\mathrm{n}=112)\end{array}$} & \multicolumn{2}{c|}{$\begin{array}{c}\text { Дівчата } \\
(\mathrm{n}=98)\end{array}$} & \multicolumn{2}{c|}{$\begin{array}{l}\text { Усього } \\
\text { (n=210) }\end{array}$} \\
\cline { 2 - 7 } & абс. & $\%$ & абс. & абс. & 39 & 18,7 \\
\hline Негативна & 17 & 15,4 & 22 & 22,3 & 85 & 40,6 \\
\hline $\begin{array}{l}\text { слабопози- } \\
\text { тивна }\end{array}$ & 43 & 39,1 & 41 & 42,0 & 86 & 40,7 \\
\hline Позитивна & 52 & 5,5 & 35 & 35,7 & 86 \\
\hline
\end{tabular}

При визначенні стану гігієни ротової порожнини у підлітків було встановлено, що доброю вона була у $10 \%$ (21 особа), з яких 8 \% - 9 хлопців та 12,9 \% - 12 дівчат. Задовільною була гігієна у 24,8 \% (52 особи), серед яких 23,3 \% - 26 хлопців та 26,5 \% - 26 дівчат. Гігієну оцінили як незадовільну в $39 \%$ - 82 обстежених, зокрема у 42 \% - 47 хлопців та 35,7 \% - 35 дівчат. Поганою гігієна була у $26,2 \%$ - 55 обстежених, 26,7 \% - 30 хлопців та 25,5 \% - 25 дівчат (табл. 4).
При обрахуванні індексу CPITN встановлено, що не потребували лікування тканин пародонта 18,7 \% - 39 дітей, зокрема 9,7 \% - 11 хлопців та 28,6 \% - 28 дівчат. Потребували покращення гігієнічного догляду 70,5 \% - 148 дітей, серед них 75 \% - 84 хлопців та 65,3 \% - 64 дівчат. Потребували лікування тканин пародонта 10,9 \% - 23 обстежених, 15,9 \% - 17 хлопців та 6,1 \% -6 дівчат (табл. 5).

Результати аналізу стану ясенного краю встановили, що в нормі він перебував у 28,5 \% 
Дитяча стоматологія

Таблиця 4. Стан гігієни ротової порожнини за гігієнічним індексом Green-Vermillion у підлітків 15-16 років

\begin{tabular}{|l|c|c|c|c|c|c|}
\hline \multirow{2}{*}{ Стан гігієни } & \multicolumn{2}{|c|}{$\begin{array}{c}\text { Хлопці } \\
(\mathrm{n}=112)\end{array}$} & \multicolumn{2}{c|}{$\begin{array}{c}\text { Дівчата } \\
(\mathrm{n}=98)\end{array}$} \\
\cline { 2 - 7 } & абс. & $\%$ & абс. & $\%$ & Усього \\
(n=210)
\end{tabular}

Таблиия 5. Визначення стану гігієни ротової порожнини

\begin{tabular}{|c|c|c|c|c|c|c|}
\hline \multirow{2}{*}{ Стан гігієни } & \multicolumn{2}{|c|}{$\begin{array}{l}\text { Хлопці } \\
(\mathrm{n}=112)\end{array}$} & \multicolumn{2}{|c|}{$\begin{array}{l}\text { Дівчата } \\
(\mathrm{n}=98)\end{array}$} & \multicolumn{2}{|c|}{$\begin{array}{l}\text { Усього } \\
(\mathrm{n}=210)\end{array}$} \\
\hline & абс. & $\%$ & абс. & $\%$ & абс. & $\%$ \\
\hline Не потребує & 11 & 9,7 & 28 & 28,6 & 39 & 18,6 \\
\hline Необхідне покращення гігієни & 84 & 75 & 64 & 65,3 & 148 & 70,5 \\
\hline $\begin{array}{l}\text { Необхідне пародонтологічне } \\
\text { лікування }\end{array}$ & 17 & 15,9 & 6 & 6,1 & 23 & 10,9 \\
\hline
\end{tabular}

- 60 обстежених (22 \% - 25 хлопців; 35,7 \% - 35 дівчат). Ясенний край був щільний у 18,6 \% 39 дітей (7 \% - 19 хлопців; 20,5 \% - 20 дівчат) (табл. 6).

Ясенний край був набряклий та гіперемійований у 14,3 \% - 29 дітей (16 \% - 18 хлопців;
11,2 \% - 11 дівчат); кровоточивість діагностували у 12,4 \% - 26 обстежених (15,8 \% - 17 хлопців; 9,2 \% - 9 дівчат); пастозність відзначали у 6,2 \% - 13 дітей (6 \% -7 хлопців; 6,1 \% - 6 дівчат); ціанотичний відтінок - у 6,7 \% - 14 дітей (7,2 \% - 8 хлопців; 6,1 \% - 6 дівчат).

Tаблищя 6. Визначення стану ясенного краю у підлітків 15-16 років

\begin{tabular}{|l|c|c|c|c|c|c|}
\hline \multirow{2}{*}{ Стан ясенного краю } & \multicolumn{2}{|c|}{$\begin{array}{c}\text { Хлопці } \\
(\mathrm{n}=112)\end{array}$} & \multicolumn{2}{c|}{$\begin{array}{c}\text { дівчата } \\
(\mathrm{n}=98)\end{array}$} \\
\cline { 2 - 7 } & абс. & $\%$ & абс. & $\%$ & \multicolumn{2}{c|}{$\begin{array}{c}\text { Всього } \\
(\mathrm{n}=210)\end{array}$} \\
\hline Норма & 25 & 22 & 35 & 35,7 & 60 & 28,5 \\
\hline Край ясен щільний & 19 & 17 & 20 & 20,5 & 39 & 18,6 \\
\hline Край ясен пастозний & 7 & 6 & 6 & 6,1 & 13 & 6,2 \\
\hline Край ясен набряклий & 18 & 16 & 11 & 11,2 & 29 & 13,8 \\
\hline Кровоточивість & 17 & 15,8 & 9 & 9,2 & 26 & 12,4 \\
\hline Гіперемія & 18 & 16 & 11 & 11,2 & 29 & 13,8 \\
\hline Ціанотичність & 8 & 7,2 & 6 & 6,1 & 14 & 6,7 \\
\hline
\end{tabular}

У значного відсотка обстежених було діагностовано катаральний гінгівіт, 48 \% - 101

дитина (67,9 \% - 76 хлопців; 25,4 \% - 25 дівчат) (табл. 7).

Таблищя 7. Структура гінгівіту в підлітків 15-16 років

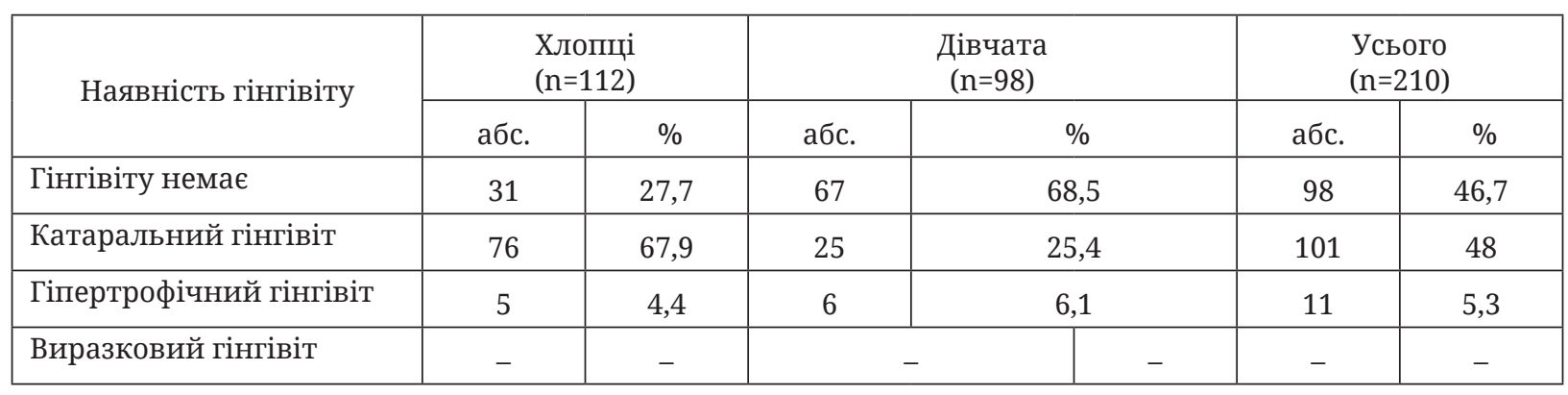


Гіпертрофічний гінгівіт діагностували у 5,3 \% - 11 дітей (4,4 \% - 5 хлопців; 6,1 \% - 6 дівчат).

Висновки. Основною причиною звернення підлітків за пародонтологічною допомогою $є$ наявність проблем зі станом слизової оболонки ротової порожнини і пародонта. У структурі пародонтологічної патології превалює більшою мірою катаральний гінгівіт 48 \% (101/210). Це пов’язано 3 незадовільною та поганою гігієною ротової порожнини, що підтверджено отриманими результатами (у 26,2 \%) та незадовільною (у 39 \%) гігієною порожнини рота в обстежених. Дана ситуація потребує розробки та впровадження комплексної регіональної програми профілактики основних стоматологічних захворювань серед підлітків 15-16 років м. Краматорськ, яка базується на покращенні раціональної гігієни порожнини рота з подальшим контролем.

\author{
(С). П. Ярова, Е. В. Новикова, Ю. Ю. Яров
}

Донецкий национальный медицинский университет, г. Лиман

\title{
Состояние гигиены ротовой полости и структура пародонтологической патологии у подростков 15-16 лет
}

Резюме. Кариес зубов и болезни пародонта относятся к числу наиболее распространенных заболеваний человека. Оценку их распространенности и интенсивности в масштабах государства осуществляют с помощью эпидемиологических исследований. Изучение эпидемиологии стоматологических заболеваний среди детского населения Донецкой области лежит в основе планирования и организации стоматологической помощи детям, выявления потребности в профилактике и лечении, а также позволяет оценить качественный уровень лечебных и профилактических мероприятий. Распространенность заболеваний пародонта у детей достигает 35-40 \%. По данным современной литературы ведущим фактором развития воспалительных заболеваний тканей пародонта является гигиена ротовой полости.

Цель исследования - изучить состояние гигиены ротовой полости и структуру пародонтологической патологии у подростков в возрасте 15-16 лет г. Краматорск.

Материалы и методы. В исследование применили клинические (осмотр, анамнез), параклинические (проба Писарева-Шиллера, ПМА, СРITN) методы, гигиеническое состояние оценивали по ГИ Green-Vermillion.

Результаты исследований и их обсуждение. Результаты показали, что в структуре пародонтологической патологии превалирует в большей степени катаральный гингивит - 48 \%. Гигиеническое состояние ротовой полости по ГИ Green-Vermillion соответствует «плохому» (26,2 \%) и «неудовлетворительному» (39 \%).

Выводы. Гигиена полости рта является ведущим фактором развития воспалительных заболеваний тканей пародонта у подростков 15-16 лет, что требует разработки лечебно-профилактических комплексов, обеспечивающих поддержку гигиенического состояния на «удовлетворительном» уровне.

Ключевые слова: дети; эпидемиология стоматологических заболеваний; гингивит; гигиена ротовой полости.

\author{
CS. P. Jarova, K. V. Novikova, Y. Y. Jarov \\ Donetsk National Medical University, Lyman
}

\section{The state of oral hygiene and the structure of periodontal pathology in adolescents 15-16 years old}

Symmary. Dental caries and periodontal diseases are among the most common human diseases. The assessment of the prevalence and intensity across the state is carried out by epidemiological studies. The study of the epidemiology of dental disease among children of Donetsk region underlies the planning and organizing dental care for children, identifying the need for prevention and treatment, as well as enables to evaluate the quality of the medical and preventive measures [1,2]. The study of the epidemiology of dental diseases among the children of the Donetsk region underlies the planning and organization of dental care for children, identifying the need for prevention and treatment, and also allows you to assess the quality 


\section{Дитяча стоматологія}

level of medical and preventive measures. The spread of gingivitis in children reaches 35-40 \%. According to the literature the leading factor in the development of inflammatory diseases of periodontal tissues is oral hygiene.

The aim of the study - to learn the state of oral hygiene and the structure of periodontal pathology in teenagers aged 15-16 years old in Kramatorsk.

Materials and Methods. Clinical (medical examination, anamnesis), paraclinical (Pisarev-Schiller test, PMA, CPITN), hygienic condition was evaluated by Green-Vermillion hygiene index.

Results and Discussion. The previous test showed that catarrhal gingivitis is more prevalent in periodontal pathology (48\%). The hygienic condition of the oral cavity according to Green-Vermillion hygiene index scale is "poor" (26.2 \%) and "unsatisfactory" (39\%).

Conclusions. Thus, oral hygiene is a leading factor in the development of inflammatory diseases of periodontal tissues in teenagers aged 15-16 years old, which requires the development of therapeutic and prophylactic complexes that support the hygienic state at a "satisfactory" level.

Key words: children; epidemiology of dental diseases; gingivitis; oral hygiene.

\section{СПИСОК ЛІТЕРАТУРИ}

1. Борисенко А. В. Захворювання пародонта та їх вплив на загальний стан організму / А. В. Борисенко // Журнал практичного лікаря. - 2005. - № 5. C. $14-18$.

2. Каськова Л. Ф. Поширеність зубощелепних аномалій та стан твердих тканин зубів і тканин пародонта в дітей 11-16 років / Л. Ф. Каськова, Н. М. Тараненко // Український стоматологічний альманах. - 2005. - № 1. - С. 51-54.

3. Методичне керівництво для стоматологів по впровадженню комплексної профілактики стоматологічних захворювань у дитячого населення України / К. Н. Косенко, О. В. Деньга, Л. О. Хоменко, П. О. Леус. - Одеса, 2006. - 43 с.

4. Клітинська О. В. Аналіз поширеності карієсу у дітей дошкільного віку міста Ужгорода / О.В.Клітинська, Е. Й. Дячук // Матеріали науково-практичної конференції «Актуальні питання стоматології сьогодення». - Тернопіль, 2010. - С. 24-25.

5. Клітинська О. В. Аналіз стану твердих тканин зубів у дітей, які проживають в умовах біогео-хімічного дефіциту фтору та йоду / О.В.Клітинська // Матеріали науково-практичної конференції «Актуальні питання стоматології сьогодення». - Тернопіль, 2010. - С. 20-21.

\section{REFERENCES}

1. Borisenko, A.V. (2005). Zakhvoriuvannia parodonta ta yikh vplyv na zahalnyi stan orhanizmu [Periodontal disease and their effect on the general state of the organism]. Zhurnal praktychnoho likaria-Journal of the Practitioner, 5, 14-18 [in Ukainian].

2. Kaskova, L.F., \& Taranenko, N.M. (2005). Poshyrenist zuboshchelepnykh anomalii ta stan tverdykh tkanyn zubiv i tkanyn parodonta v ditei 11-16 rokiv [Prevalence of dentoalveolar anomalies and the state of hard teeth and periodontal tissues in children aged 11-16 years]. Ukrainskyi stomatolohichnyi almanakh - Ukrainian Dental Almanac, 1, 51-54 [in Ukrainian].

3. Kosenko, K.N., Denha, O.V., Homenko, L.O., \& Leus, P.O. (2006). Metodychne kerivnytstvo dlia
6. Терапевтична стоматологія дитячого віку : підручник / Л. О. Хоменко, О.І. Остапко, О. Ф. Кононович [та ін.]. - К. : Книга плюс, 2007. - 766 с.

7. Loe H. Oral hygiene in the prevention of caries and periodontal disease / H. Loe // Int. Dent. J. - 2000. No. 50 (3). - P. 129-139.

8 . Wu C. D. Evaluation of the safety and efficacy of overthe-counter oral hygiene products for the reduction and control of plaque and gingivitis / C. D. Wu, E. D. Savitt // Periodontol. - 2008. - P. 28-35.

9. Gaffar A. Applications of polymers in dentifrices and mouthrinses / A. Gaffar, C. M. Hunter, Y. R. Mirajkar // J. Clin. Dent. - 2008. - No. 13 (4). - P. 138-148.

10. The effect of a triclosan-containing dentifrice on the progression of periodontal disease in an adult population / M. P. Cullinan, B. B. Westerman, S. M. Hamlet, J. E. Palmer // J. Clin Periodontol. - 2009. No. 30 (5). - P. 414-419.

11. Acquisition and loss of Porphyromonas gingivalis, Actinobacillus actinomycetemcomitans and Prevotella intermedia over a 5-year period: effect of a triclosan/ copolymer dentifrice / M. P. Cullinan, S. M. Hamlet, B. B. Westerman [et al.] // J. Clin. Periodontol. - 2009. No. 30 (6). - P. 532-554.

stomatolohiv po vprovadzhenniu kompleksnoi profilaktyky stomatolohichnykh zakhvoriuvan $u$ dytiachoho naselennia Ukrainy [Methodical guide for dentists on the implementation of complex prevention of dental diseases in the pediatric population of Ukraine]. Odesa [in Ukrainian].

4. Klitinska, O.V., \& Diachuk, E.Y. (2010). Analiz poshyrenosti kariiesu u ditei doshkilnoho viku mista Uzhhoroda [Analysis of the prevalence of caries in preschool children in Uzhhorod]. Proceedings of the Scientific and Practical Conference : "Aktualni pytannia stomatolohii sohodennia" - "Topical Issues of Dentistry of Today". (pp. 24-25). Ternopil [in Ukrainian].

5. Klitinska, O.V. (2010). Analiz stanu tverdykh tkanyn 
zubiv u ditei, yaki prozhyvaiut $\mathrm{v}$ umovakh bioheokhimichnoho defitsytu ftoru ta yodu [Analysis of the state of hard tissues of teeth in children living in conditions of biogeochemical deficiency of fluorine and iodine]. Proceedings of the Scientific and Practical Conference : "Aktualni pytannia stomatolohii sohodennia" - "Topical Issues of Dentistry of Today". (pp. 20-21). Ternopil [in Ukrainian].

6. Homenko, L.O., Ostapko, O.I., Kononovich, O.F., Shmatko, V.I., \& Chaikovskyi, Yu.B. (2007). Terapevtychna stomatolohiia ditiachoho viku: pidruchnyk [Therapeutic dentistry of childhood: a textbook]. Kyiv: Knyha plius [in Ukrainian].

7. Loe, H. (2000). Oral hygiene in the prevention of caries and periodontal disease. Int. Dent. J., 50 (3), 129-139.

8. Wu, C.D., \& Savitt, E.D. (2008). Evaluation of the safety and efficacy of over-the-counter oral hygiene products for the reduction and control of plaque and gingivitis. Periodontol., 28-35.

9. Gaffar, A., Hunter, C.M., \& Mirajkar, Y.R. (2008). Applications of polymers in dentifrices and mouthrinses. J. Clin. Dent., 13 (4), 138-148.

10. Cullinan, M.P., Westerman, B.B., Hamlet, S.M., \& Palmer, J.E. (2009). The effect of a triclosan-containing dentifrice on the progression of periodontal disease in an adult population. J. Clin. Periodontol., 30 (5), 414-419. 11. Cullinan, M.P., Hamlet, S.M., Westerman, B.B., Palmer, J.E., Faddy, M.J., \& Seymour, G.J. (2009). Acquisition and loss of Porphyromonas gingivalis, Actinobacillus actinomycetemcomitans and Prevotella intermedia over a 5-year period: effect of a triclosan/ copolymer dentifrice. J. Clin. Periodontol., 30 (6), 532554. 